\title{
Title: Employer and academic staff perceptions of science and engineering graduate competencies
}

Khoo, E.*, Zegwaard, K. and Adam, A.

*Corresponding author:

Dr Elaine Khoo

Senior Research Fellow

Wilf Malcolm Institute of Educational Research (WMIER)

Division of Education

The University of Waikato

Private Bag 3105

Hamilton 3240

New Zealand

Phone: +64 7838 4466x6260

Email: elaine.khoo@waikato.ac.nz

ORCiD: http://orcid.org/0000-0002-4260-4553

Dr Karsten Zegwaard

Director of Work-Integrated Learning Research

Office of the Vice-Chancellor

The University of Waikato

Private Bag 3105

Hamilton 3240

New Zealand

Phone: +64 78384892

Email: karsten.zegwaard@waikato.ac.nz

ORCiD: https://orcid.org/0000-0002-1948-635X

Dr Aminath Shafiya Adam

Assistant Professor

Faculty of Education

The Maldives National University

Rahdhebai Higun, Machangolhi

Male'

20371

Maldives

Phone: +960 7937227

Email: aminath.shafiya@mnu.edu.mv 


\title{
Employer and academic staff perceptions of science and engineering graduate competencies
}

\begin{abstract}
This paper reports on the findings from a study investigating science and engineering employers and university academic teaching staff perceptions of the competencies science and engineering recent graduates require in the workplace. Data were collected through surveys and focus group interviews of science and engineering employers and academic teaching staff. Participants rated 26 graduate competencies on how important they are for graduates entering the science and engineering workplace across three aspects: important today, important in 10 years' time, and, the perceived competency performance level of recent graduates that have entered the workplace. The findings revealed that employers thought teamwork, written communication, problem solving, oral communication, and interpersonal relationships were particularly important for today while academic teaching staff, however, viewed problem solving, written communication, critical thinking, conceptual thinking, and oral communication to be important today. The findings offer insights into the extent current preparation of science and engineering students are meeting employer expectations and highlight shifts in perceived future competencies to enhance support for student learning and employability outcomes. Implications are offered for strengthening curriculum, pedagogy and assessment approaches for workplace preparation. Finally, we discuss the limitations of the present study and how future research might resolve those limitations.
\end{abstract}

\section{Keywords:}

Science and engineering graduate competencies, employer perceptions, academic staff perceptions, graduate performance, employability, mixed-methods.

\section{Introduction}

Universities are under increasing pressure to develop work-ready graduates with specific disciplinary knowledge and skills and dispositions necessary to ensure their capacity to contribute productively to an organisation's objectives (Burke, Scurry, Blenkinsopp, \& Graley, 2016; Rowe \& Zegwaard, 2017). The imperative is that tertiary education enables students to possess relevant work-ready skills and lifelong learning competencies. This is important in today's rapidly changing and complex workplace.

In the context of science and engineering, in addition to technical competencies, science and engineering graduates are expected to develop strong professional or non-technical competencies. These include, for example, communication skills, practical ingenuity, and good written and oral communication skills (Chhinzer \& Russo, 2018; Coll \& Zegwaard, 2012; Jackson, 2012; Naylor, 2016; Scott \& Yates, 2002) as well as an understanding of organisational and managerial abilities (Lizunkov, Marchuk, \& Podzorova, 2015), business practices, and, a sense of social, ethical, political, and human responsibility (Campbell \& Zegwaard, 2015; Zegwaard, Campbell, \& Pretti, 2017). The New Zealand Tertiary Education Strategy 2014-2019 outlined the priority areas for tertiary education; one of which requires tertiary educators to develop curriculum and pedagogy to include the use of new technologies and foster more explicit cooperation between industry and Tertiary Education Organisations (TEOs) (Ministry of Education \& Ministry of Business, 2014). This encompasses supporting the development of non-technical competencies that are needed in all workplaces such as communicating well, processing information effectively, thinking logically and critically and adapting to future change (Ministry of Education \& Ministry of Business, 2014). The aim is to develop 
work-ready graduates with specific disciplinary knowledge, skills, and dispositions necessary to contribute productively in today's rapidly changing and complex workplace. Although the need to support and facilitate the development of work-ready graduates is not novel nor is it the only responsibility of university educators, the current government imperative has raised the urgency and pushed student employability outcomes to the fore in discussions regarding the future of New Zealand education (e.g., Ministry of Education, 2019). There is evidence, however, that tertiary institutions face challenges in providing relevant and authentic curricula to enable students to develop these competencies and dispositions (Bennett, Richardson, \& MacKinnon, 2016; Guilbert, Bernaud, Gouvernet, \& Rossier, 2016; Khoo, Zegwaard, Adam, Peter, \& Cowie, 2017a; Mason, Williams, \& Cranmer, 2009; Rowe \& Zegwaard, 2017; Zegwaard \& McCurdy, 2014).

There often is confusion in the literature between the concept of employment outcomes and employability outcomes (Burke, Scurry, Blenkinsopp, \& Graley, 2016; Rowe \& Zegwaard, 2017). Employment outcomes involve securing employment and employment related elements such as salary and position, while employability outcomes are the conceptualisation of skills, capabilities, and personal attributes deemed important by the workplace and needed to be able to secure relevant employment. The similarity of these two concepts highlights the complex nature of employability and employment and explains why authors such as Bennett, Richardson, and MacKinnon (2016) and Guilbert, Bernaud, Gouvernet, and Rossier (2016) argue that employability is a multi-dimensional concept not limited to economic outcomes and employment outcomes.

The complex nature of employability outcomes, including understandings of the competencies and capabilities that underpin employability outcomes, have been subjected to significant on-going work (e.g Male, Bush, \& Chapman, 2011; Passow \& Passow, 2017; Scott, Chang, \& Grebennikov, 2010). However, there is still need for further work to clarify these underpinning competencies and how these shifts over time.

This paper reports on the findings from an aspect of a funded study investigating current science and engineering stakeholders' perceptions of the essential graduate competencies to be successful in the workplace (Khoo, Zegwaard, Peter, Adam, \& Cowie, 2017b). We focus specifically on science and engineering employers and academic staff perspectives; their views on the extent university teachinglearning strategies are productive in preparing students for the workplace, current and future competencies important for students to be successful in the workplace, and their suggestions for enhancing current curriculum, pedagogy, and assessment approaches.

\section{Investigating graduate competencies}

The term 'competency' has been widely interpreted in the literature and tends to be used interchangeably with skills, capabilities, and/or attributes (Barrie, 2006; Fleming, Martin, Hughes, \& Zinn, 2009; Weisz, 2000). The literature from the past two decades have documented different examples and attempts at clarifying this term. For example, competency can be seen to be the underlying personal characteristics of an individual that facilitate superior performance in a given situation (Spencer \& Spencer, 1993). While Daelmans, Hoogenboom, Scherpbier, Stehouwer, and Van Der Vleuten (2005) consider competency as the ability of a professional to handle complex situations or problems using professional knowledge, skills and attitudes in an integrative way. Both Mulder, Weigel, and Collins (2007) and Passow (2012) affirm competency as the knowledge, skills, abilities, attitudes, and other characteristics that enable a person to perform skillfully (i.e., to make sound decisions and take effective action) in complex and uncertain situations such as professional work, civic engagement, and personal life

Yet others extend this notion to encompass the emotional and cognitive intelligence required to apply specific and generic skills and knowledge for a role as elaborated in the Professional Capability 
Framework by Scott, Chang, and Grebennikov (2010). They go further to differentiate competencies from capabilities by explaining that competencies can be taught but capabilities can only be learned through solving real-world dilemmas when one deals with the unexpected and reflects on what has or has not worked in a situation. Male, Bush, and Chapman (2011) adopted a more holistic view of the term competency proposed by the Definition and Selection of Competencies (DeSeCo) Project, commissioned by the Organisation for Economic Cooperation and Development (OECD), to describe competencies as complex due to the kinds of external demands, individual capacities and context that impact on individuals' observable actions in particular situations.

For the purposes of this paper, which builds on earlier studies on employer views (Coll, Zegwaard, \& Hodges, 2002) and faculty views (Zegwaard \& Hodges, 2003), and to enable similar comparisons to be undertaken, the term 'competency' is considered as; "the manner in which individual attributes such as knowledge, skills and attitudes are drawn on in performing tasks in specific work contexts, which result in overall job performance" (Coll et al., 2002, p. 31). We also agree with Birkett (1993) who emphasises the contextualised and embedded nature of how a competence might be demonstrated, "neither contextual task performance or individual attributes constitute competence; it is the relation between the two that does" (p. 4).

In the last few decades, a plethora of studies have reported on the range of competencies valued in the science and engineering discipline. The AC Nielsen (2000) survey of employer satisfaction with graduate skills identified perceived generic skill deficiencies to commonly include a lack of communication skills; a lack of interpersonal skills; and a lack of understanding of business practice. Employers identified that for the future, graduates will require skills such as adaptability and flexibility including the need for continuous learning and re-training throughout their careers. This list has been extended over the recent years. For example, Passow (2012) found competencies such as teamwork, communication, data analysis, and problem solving were highly important from a survey of engineering graduates concerning competencies important for professional practice. Additionally, Pons (2016) surveyed New Zealand practicing engineers and highlighted communication and project planning to be important additions to the list of competencies identified in the literature.

A study conducted by Coll et al. (2002), on which this study is based, sought to identify similarities between science and technology employers and business sector employers in terms of the most important workplace competencies required of new graduates then and in 10 years' time. Of the 25 competencies (technical and non-technical), employers rated both technical and non-technical skills to be important and predicted very little shifts in the order of rankings within a decade. They, however, did think all competencies would be more important in 10 years' time. Science and engineering employers considered competencies such as ability and willingness to learn, teamwork and cooperation, initiative, and analytical thinking with concern for order, quality and accuracy, computer literacy to be important and written communication skills to be next important. The study reported in this paper sought to extend that study by using an updated list of competencies based on emerging literature to ascertain shifts in employer and academic staff perceptions.

Several other studies also affirm the importance of both technical and non-technical competencies (e.g., De Graaff \& Ravesteijn, 2001; Male et al., 2011). Male et al. (2011) found high importance for competencies such as communication, working in diverse teams, and self-management. Further, they identified attitudinal components such as commitment, honesty, self-motivation, demeanour, creativity, and concern for others to be valued by employers.

Recent studies have sought to organise the various graduate competencies more systematically into frameworks or models of competencies. For example, Scott et al. (2010) introduced a professional capability framework that involves five dimensions of interrelated competence and capability. Their 
framework highlights three professional capabilities (personal, interpersonal and cognitive) which are underpinned by two main competencies (role-specific and generic competencies). These competencies relate to the skills and knowledge essential to a specific role.

In the New Zealand context, the Ministry of Education (2016) has proposed an Employability Skills Framework based on responses from employer and workplace representatives, government agencies and educators to highlight characteristics such as: (1) positive attitude; (2) communication; (3) teamwork; (4) self-management; (5) willingness to learn; (6) thinking skills (problem-solving and decision-making); and, (7) resilience. Along similar lines, other examples such as the Graduate Employability framework (Archer \& Davison, 2008), Graduate Capability Framework for Environmental Engineering Degree Programs (Dowling \& Hadgraft, 2013) and Systems Engineering Competency Framework (Hubbard, 2012) have also been proposed by specific engineering subdisciplines as attempts to synthesise and evaluate the kinds and categories of competencies valued in contemporary.

\section{Research Context}

\section{Research Aim}

This reported study took place at the University of Waikato in New Zealand. The university is a research-intensive university which had embarked on a major curricular review and redesign, making it compulsory for all students enrolled in an undergraduate degree from 2018 onwards to complete at least one subject/course offering in work-integrated learning (WIL), with the intent of developing workplace competencies and increasing employability outcomes. A current investigation into the kinds of competencies valued by key stakeholders involved in supporting student learning and preparation for the workplace is, therefore, warranted as an initial step for (re)designing student university and workplace experiences to ensure coherence and foster more authentic application of theoretical ideas in real-world contexts.

This study is part of a bigger funded research project aimed at investigating science and engineering stakeholders' views of the competencies and dispositions science and engineering students need to be successful in the workplace, and to inform current workplace preparation curriculum

(re)development, teaching and assessment approaches (Khoo et al., 2017b). The stakeholders involved included science and engineering employers, academic teaching staff, students, and recent alumni. For the purposes of this paper, only the data collected from employer and academic teaching staff perspectives will be reported.

A unique feature was the comparison between what employers and academic staff predicted as essential workplace competencies needed in 10 years to what they currently value. Aside from earlier work foundational to this study (Coll et al., 2002; Zegwaard \& Hodges, 2003) to our knowledge, no recent publications exist that scope this kind of longer-term development of science and engineering stakeholder expectations. Such findings will provide valuable information on how the current preparation of science and engineering students are meeting employer expectations, provide feedback on future shifts employers see, and allow the university to use this information to modify current curriculum, pedagogical, and assessment activities.

The research aims were translated into the following research questions:

1. What are science and engineering stakeholder perceptions of current graduates' work-readiness for the science profession and engineering profession?

2. What are science and engineering stakeholder perceptions of important competencies students must possess to be work-ready for the science profession and engineering profession? 
3. What are science and engineering stakeholder views of the competencies that will be valued in 10 years' time?

\section{Research Design and Data Collection}

The study adopted a mixed-method approach using a combination of surveys and focus group interviews. This approach is appropriate for researchers seeking to "represent a plurality of interests, voices, and perspective" (Greene \& Caracelli, 1997, p. 14) about the research topic.

Each of the 26 competencies can be operationally identified and supported by relevant literature (see Appendix 1 for supporting literature justifying each dimension of competency, and Appendix 2 for definitions).

The survey was conducted via an online platform using LimeSurvey, which collected:

1. Demographic data;

2. Ratings of 26 graduate competencies in terms of importance today, in 10 years' time, and, the competency level of recent graduates (within the last five years). The 26 competencies were categorised broadly into five dimensions:

- Communication and Teamwork skills - oral communication, written communication, interpersonal relationship, digital interpersonal skills and teamwork;

- Leadership and Management skills - leadership, staff management, project management, financial literacy, organisational awareness;

- Analytical skills - problem solving, data analysis, critical thinking, conceptual thinking, creative thinking, conceptual knowledge;

- Lifelong Learning and Self-Management skills - computer/ICT skills, self-management, adaptability, help seeking, continuous learning; and,

- Global Awareness skills - environmental sustainability, societal responsibility, ethical responsibility, cultural awareness, and, global awareness.

3. Open ended questions on additional competencies and how universities could better prepare graduates for the workplace.

Participants were asked in the survey to rate the importance of each competency using a 7-point Likert scale ( $1=$ not at all important, $7=$ extremely important) and then rate their perception of new graduates' performance on each of these competencies ( $1=$ not at all competent, $7=$ extremely competent).

A series of employer focus group interviews were conducted to obtain further insights into stakeholders' rationale for selecting particular competencies as important and to their proposed strategies for supporting students' development of these competencies as part of their university learning experiences. The interviews obtained in-depth and detailed responses to complement the breadth of findings from the survey. All focus groups were transcribed and verified with participants before inclusion in the analysis. No focus groups were conducted with academic staff due to constraints of time and resource.

Quantitative data were analysed using SPSS and Excel to report on descriptive statistics to determine the means and significance of differences $(p=<.05)$ between the data sets. Data distribution was normal, allowing for the use of the Student's t-test of significance of difference. Qualitative data were thematically analysed (informed by work by Braun \& Clarke, 2006) using the NVivo software. Each form of data was analysed separately and then triangulated to address the research questions. 
The study was approved by the university's Human Research Ethics Committee and all participants participated on a voluntary basis.

\section{Analysis and Findings}

\section{Demographic background \\ Participants}

The science and engineering participants consisted of employers and academic teaching staff.

\section{Employer Participants}

Employer participants were derived from the university's science and engineering database of employers known to employ science and engineering students and graduates, and are active stakeholders of the science and engineering work placement programme. These employers were from organisations ranging primarily from small to medium sized enterprise (SME; less than 20 employees) to large companies (e.g., up to 20,000 employees). The survey was sent out to 1,159 employers and received 248 responses that provided 210 usable responses (18\% return rate). Four online and face-to-face focus group interviews were further held with 17 voluntary employers across different organisations.

A majority of the employer participants were male (75\%) while $25 \%$ were female. Participants mostly held postgraduate qualifications (33\%), 20\% holding PhD qualifications, $13 \%$ with Masters, $23 \%$ were first degree holders, and 16\% with either Certificate or Diploma qualifications. Another $6 \%$ had 'Other' qualifications such as industry gained accreditation, specialised trade qualifications, and so forth.

Most participants were managers (59\%), followed by supervisors (12\%), while another $10 \%$ respectively identified themselves to be non-supervisory team members and having 'Other' roles. Finally, 9\% held the position of chief executive officer (CEOs).

Of the 210 employer participants, $45 \%$ reported that they worked in a primarily engineering-based workplace (e.g., civil, environmental, chemical, biological, materials \& process, mechanical, systems, etc.), $21 \%$ in primarily in a science-based workplace (e.g., earth sciences, biological sciences, chemistry, computer science, etc.), and 34\% indicated 'Other' industries related to science and engineering. The industries provided for the Other category ranged from, for example, agriculture to dairy processing, manufacturing, aviation, mining, food and beverage, conservation, tourism, public safety, and local government, without clear indication if these roles are primarily engineering or science related. The majority of employer participants were experienced in their reported workplace practice with $78 \%$ having more than 10 years' experience, $13 \%$ between 6 to 10 years' experience, $7 \%$ between 3 to 5 years' experience, and the remaining having 1 to 2 years' experience.

\section{Academic staff Participants}

Academic staff participants consisted of science and engineering academic teaching staff at the University of Waikato's School of Engineering and School of Science, in addition to the School of Computing and Mathematical Sciences that offers the disciplines of software engineering and computer science. The survey was made available to 158 staff and had 66 responses, from which 46 usable responses were obtained ( $29 \%$ return rate).

Of the responses received, $76 \%$ were male and $24 \%$ were female; $54 \%$ were from the School of Science, $20 \%$ from the School of Engineering and 26\% from the School of Computing and Mathematical Sciences, which is broadly reflective of the respective School sizes. A majority of participants had $\mathrm{PhD}$ 
qualifications (89\%), while $4 \%$ held Masters qualifications and a further $7 \%$ were first degree holders. Thirteen percent were involved in arranging student work placement in some capacity either as part of coursework or as coordinator of programmes.

\section{Employer ratings of important workplace competencies}

Although employers perceived all competencies to be important, they rated competencies such as teamwork, written communication, problem solving, oral communication, and interpersonal relationships as the top five important competencies for today (Table 1). Employers thought that in 10 years' time, the top five most important competencies graduates needed would be problem solving, computer/ICT use, teamwork, written communication, and self-management skills. The lowest ranked competencies were digital interpersonal skills, leadership, staff management, financial literacy, and global awareness (in decreasing order of importance). This trend seems to persist in terms of their perceived importance in 10 years' time and current graduates' competency level with the exception of digital interpersonal skills (ranked at 7 th).

When comparing the importance of each competency to new graduates' performance of each competency, the data indicated a significant $(\mathrm{p}=<.05)$ 'performance gap' for each competency except in computer/ICT use and digital interpersonal skills. The largest gaps between competencies important today and performance were observed for written communication, critical thinking, oral communication, problem solving, and self-management, each of which are in the top seven of important competencies. The smallest gaps were observed for competencies such as digital interpersonal skills, computer/ICT use, cultural awareness, environmental sustainability, and global awareness, with the differences between digital interpersonal skills and computer/ICT use not being statistically significant ( $\mathrm{p}=>.05)$.

A further comparison of the difference between employer's perceived importance of competencies today and in 10 years' time revealed that the biggest differences $(\mathrm{p}=<.05)$ were observed for digital interpersonal skills, environmental sustainability, global awareness, computer/ICT use, and societal responsibility. The smallest differences (none statistically different; $\mathrm{p}=>.05$ ) between now and 10 years' time were observed for the competencies (in descending order) help seeking, teamwork, technical knowledge, interpersonal relationships, and oral communication.

Comparing employer (Table 1) and academic staff (Table 2) ratings, academic staff tended to rate the important competencies higher $(\mathrm{p}=<.05)$ than employers ( 12 out of 26 times) which included three of the top five competencies, problem solving, critical thinking, and self-management. Additionally, financial literacy (ranked 25th for competency important today by employers) and global awareness (ranked last for competency important today and second last for competency important in 10 years' time by employers) were ranked higher $(\mathrm{p}=<.05)$ by academic staff than employers. Employers, however, rated the top five perceived graduate performance higher $(\mathrm{p}=<.05)$ than academic staff for continuous learning, interpersonal relationships, and teamwork. 
Table 1: Employer ratings using a 7-point Likert scale of competencies important today, in 10 years' time, and perceived current graduate competency level, with comparison of 'important today' to graduate competency level (competency gap) $(\mathrm{n}=210)$.

\begin{tabular}{|c|c|c|c|c|c|c|c|c|c|c|c|c|c|}
\hline & \multicolumn{3}{|c|}{ Important today } & \multicolumn{3}{|c|}{ Important in 10 years } & \multicolumn{5}{|c|}{$\begin{array}{ll}\text { Current graduate competence } \\
\text { level }\end{array} \begin{array}{l}\text { Difference today and } \\
\text { 10 years' time }\end{array}$} & \multicolumn{2}{|c|}{$\begin{array}{l}\text { Difference today and } \\
\text { graduate competence } \\
\text { level rating }\end{array}$} \\
\hline & $\begin{array}{l}\text { Mean } \\
\text { rating }\end{array}$ & $\begin{array}{l} \pm 0.05 \\
\text { alpha } \\
\text { value }\end{array}$ & Ranking & $\begin{array}{l}\text { Mean } \\
\text { rating }\end{array}$ & $\begin{array}{l} \pm 0.05 \\
\text { alpha } \\
\text { value }\end{array}$ & Ranking & $\begin{array}{l}\text { Mean } \\
\text { rating }\end{array}$ & $\begin{array}{l} \pm 0.05 \\
\text { alpha } \\
\text { value }\end{array}$ & Ranking & $\begin{array}{c}\text { Size of } \\
\text { difference }\end{array}$ & Ranking & $\begin{array}{l}\text { Size of } \\
\text { difference }\end{array}$ & Ranking \\
\hline Teamwork & 6.25 & 0.1306 & 1 & 6.40 & 0.1084 & 3 & $5.09 \&$ & 0.1488 & 2 & 0.15 & 25 & $1.16^{*}$ & 14 \\
\hline Written communication & 6.15 & 0.1314 & 2 & 6.38 & 0.1150 & 4 & 4.43 & 0.1730 & 15 & 0.23 & 21 & $1.72^{*}$ & 1 \\
\hline Problem solving & $6.11^{\#}$ & 0.1399 & 3 & $6.42^{\#}$ & 0.1132 & 1 & 4.58 & 0.1664 & 9 & $0.31^{*}$ & 20 & $1.53^{*}$ & 4 \\
\hline Oral communication & 6.09 & 0.1459 & 4 & 6.30 & 0.1227 & 6 & 4.52 & 0.1524 & 11 & 0.21 & 22 & $1.57^{*}$ & 3 \\
\hline Interpersonal relationships & 5.97 & 0.1337 & 5 & 6.14 & 0.1299 & 10 & $4.99 \&$ & 0.1548 & 5 & 0.17 & 23 & $0.98^{*}$ & 18 \\
\hline Self-management & $5.96^{\#}$ & 0.1382 & 6 & 6.34 & 0.1040 & 5 & 4.50 & 0.1674 & 13 & $0.38^{*}$ & 14 & $1.46^{*}$ & 5 \\
\hline Critical thinking & $5.95^{\#}$ & 0.1481 & 7 & $6.29^{*}$ & 0.1256 & 8 & 4.24 & 0.1735 & 18 & $0.34^{*}$ & 18 & $1.71^{*}$ & 2 \\
\hline Help seeking & 5.94 & 0.1395 & 9 & 5.94 & 0.1453 & 15 & 4.94 & 0.1676 & 8 & 0.00 & 26 & $1.00^{*}$ & 17 \\
\hline Continuous learning & 5.94 & 0.1459 & 8 & 6.30 & 0.1252 & 7 & $5.09^{\star}$ & 0.1607 & 3 & $0.36^{*}$ & 16 & $0.85^{*}$ & 19 \\
\hline Adaptability & 5.81 & 0.1370 & 10 & 6.21 & 0.1221 & 9 & 5.02 & 0.1615 & 4 & $0.40^{*}$ & 11 & $0.79^{*}$ & 21 \\
\hline Ethical responsibility & 5.75 & 0.1545 & 11 & 6.09 & 0.1309 & 11 & 4.52 & 0.1868 & 12 & $0.34^{*}$ & 19 & $1.23^{*}$ & 11 \\
\hline Computer/ICT use & $5.74^{\#}$ & 0.1528 & 12 & 6.42 & 0.1203 & 2 & 5.53 & 0.1413 & 1 & $0.68^{*}$ & 4 & 0.21 & 25 \\
\hline Technical knowledge & $5.68^{\#}$ & 0.1602 & 13 & 5.85 & 0.1540 & 18 & 4.41 & 0.1762 & 16 & 0.17 & 24 & $1.27^{*}$ & 8 \\
\hline Data analysis & $5.64^{\#}$ & 0.1688 & 14 & $6.04^{*}$ & 0.1491 & 13 & $4.49 \&$ & 0.1750 & 14 & $0.40^{*}$ & 12 & $1.15^{*}$ & 15 \\
\hline Creative thinking & 5.50 & 0.1746 & 15 & 6.07 & 0.1480 & 12 & 4.19 & 0.1835 & 20 & $0.57^{*}$ & 8 & $1.31^{*}$ & 7 \\
\hline Conceptual thinking & $5.45^{\#}$ & 0.1642 & 16 & $5.81^{\#}$ & 0.1447 & 19 & 4.21 & 0.1562 & 19 & $0.36^{*}$ & 17 & $1.24^{*}$ & 9 \\
\hline Cultural awareness & 5.27 & 0.1793 & 17 & 5.90 & 0.1612 & 16 & 4.96 & 0.1760 & 6 & $0.63^{*}$ & 6 & $0.31^{*}$ & 24 \\
\hline Project management & $5.23^{\#}$ & 0.1957 & 18 & 5.73 & 0.1649 & 20 & 3.78 & 0.1731 & 22 & $0.50^{*}$ & 10 & $1.45^{*}$ & 6 \\
\hline Societal responsibility & $5.05^{\#}$ & 0.1724 & 19 & 5.71 & 0.1570 & 21 & 4.25 & 0.1779 & 17 & $0.66^{*}$ & 5 & $0.80^{*}$ & 20 \\
\hline Environmental sustainability & $4.93^{\sharp}$ & 0.1872 & 20 & $5.97^{\#}$ & 0.1640 & 14 & 4.54 & 0.1769 & 10 & $1.04^{*}$ & 2 & $0.39^{*}$ & 23 \\
\hline Organisational awareness & 4.89 & 0.1953 & 21 & 5.26 & 0.1837 & 23 & 3.74 & 0.1874 & 23 & 0.37 & 15 & $1.15^{*}$ & 16 \\
\hline Digital interpersonal skills & 4.83 & 0.2009 & 22 & 5.89 & 0.1630 & 17 & 4.96 & 0.1610 & 7 & $1.06^{*}$ & 1 & -0.13 & 26 \\
\hline Leadership & 4.82 & 0.2082 & 23 & 5.42 & 0.1839 & 22 & 3.65 & 0.1638 & 24 & $0.60^{*}$ & 7 & $1.17^{*}$ & 12 \\
\hline Staff-management & 4.71 & 0.2304 & 24 & 5.10 & 0.2015 & 24 & 3.54 & 0.1944 & 25 & 0.39 & 13 & $1.17^{*}$ & 13 \\
\hline Financial literacy & $4.47^{\#}$ & 0.2156 & 25 & 5.02 & 0.2037 & 26 & 3.23 & 0.1806 & 26 & $0.55^{*}$ & 9 & $1.24^{*}$ & 10 \\
\hline Global awareness & $4.39^{*}$ & 0.2049 & 26 & $5.09^{*}$ & 0.2077 & 25 & 3.81 & 0.1870 & 21 & $0.70^{*}$ & 3 & $0.58^{*}$ & 22 \\
\hline
\end{tabular}

Note: where \& indicates employers rated higher than staff $(\mathrm{p}=<.05),{ }^{*}$ indicates staff rated higher than employers ( $\left.\mathrm{p}=<.05\right)$, and ${ }^{*}$ indicates the size of the comparison differences was significan $(\mathrm{p}=<.05)$. The \pm alpha provides the $95 \%$ confidence range; where ranges of competencies do not overlap the difference is significant $(\mathrm{p}=<.05)$. Ranking is descending order from highest rated competency to lowest or greatest gap between rating and performance to the least. 
In focus groups, employers' thought that students' learning and developing important workplace competencies at the university can be better supported through a range of strategies. A key recommendation was for the university to incorporate more interdisciplinary approaches in learning. Employers saw such interdisciplinary capacity as vital for tackling complex and global issues today:

Helping students work together from across the university too, Engineering, Economics, Management,

Communication - we can develop greater collaboration in all those areas, not just in the strict Science area.

(Employer Focus Group 2 Participant 1; EFG2.1)

Employers added that enabling students to work on real-world projects relevant to the company or projects that sought to find solutions to real-world problems would be of value to their learning:

Bring up work problem into a university context. We've got a [problem to be solved] in the workplace, take it to university in a group ... and they work at finding a solution. (EFG1.1)

As communication skill was valued, employers suggested that offering multiple opportunities for students to develop presentation skills through project and/or group presentations was important:

A graduate presenting to a senior leadership team, they get 10 or 15 minutes to say all this, to get people on board to support them. If they can't skilfully, craft that presentation, they're starting to lose people.

(EFG4.1)

Making relevant and supporting student learning in the work placements was another key example. Employers highlight that it was essential students continue to informally learn and apply their skills while at work placement.

It's certainly unstructured [learning]. And there's a lot of -call it 'informal training' that does happen.

Not just the, 'You're doing things, you need to learn about this tech...' But there's a lot of internal presentations that happen, so people with knowledge in an area, will do a presentation to people who want to learn about that area. That will cover quite across the software engineering, to testing, to ops operations and so on. (EFG4.2)

Employers further raised that supporting students to find ways to contribute and add value, in the business sense, to an organisation while at work placement as important in their preparing for the workplace:

We have a whole lot of jobs that are routine and may feel monotonous, but if they understand why they do it, the value of why they must do it, in a standardised, recognised way, then they can ask, or challenge a process and suggest improvements. (EFG1.2)

Finally, employers importantly suggested that university-external organisations connections need to be strengthened (e.g., inviting guest lecturers from the industries, encouraging academic staff visits to the industries ongoing reviews of the mutual benefits of university-external organisations linkage). These, in turn, would allow students to be more immersed in relevant workplace contexts and help them build a collegial network with employers during their university education.

\section{Academic teaching staff ratings of important workplace competencies}

Academic teaching staff highlighted that the top five most important graduate competencies for today were problem solving, critical thinking, written and oral communication, and, self-management (Table 2). They further thought that in 10 years' time, the most important competencies graduates needed would be problem solving, critical thinking, written communication, self-management, and computer/ICT use. However, when asked for their views of current graduates' competency levels in comparison to competencies importance, similar to employers, they thought graduates' performance was below that of importance for all competencies except for digital interpersonal skills. 
From the academic staff's perspective, the lowest ranked competencies were staff management, global awareness, digital interpersonal skills, leadership, and organisational awareness (in decreasing order of importance). A similar pattern was repeated in relation to the competencies important in 10 years' time and current graduates' competency levels with the exception of digital interpersonal skills (ranked at eighth).

Comparing the gap between academic staff perceived importance of competencies today and graduates' perceived competency levels revealed that the biggest gaps were observed for critical thinking, written communication, conceptual thinking, problem solving, and data analysis skills. These competencies' mean size differences were statistically significant $(\mathrm{p}=<.05)$. However, the smallest gaps were observed for digital interpersonal skills, computer/ICT use, cultural awareness, teamwork, and adaptability. The mean size differences for these five competencies were statistically significant $(\mathrm{p}=$ $<.05)$ with the exception of digital interpersonal skills.

Comparisons between staff perceived importance of competencies today and in 10 years' time indicated the biggest mean size differences were noted for digital interpersonal skills, environmental sustainability, global awareness, cultural awareness, and leadership skills, however, only the difference for environmental sustainability was significant $(\mathrm{p}=<.05)$.

In comparing employer (Table 1) and academic staff (Table 2) mean ratings of the top five competencies, problem solving (ranked first in importance for today and in 10 years' time by staff) as well as critical thinking (ranked second in importance for today and in 10 years' time by staff) were rated significantly higher by academic staff than employers $(\mathrm{p}=<.05)$. Self-management skills (ranked fifth in importance today by staff) was similarly rated to be significantly higher by staff than employers $(p=<.05)$. This same trend of significantly higher ratings by staff than employers was also observed for the lower ranked competencies, global awareness (ranked 24 in terms of importance for today and 21 for importance in 10 years' time by staff).

In contrast, teamwork (ranked fourth for current perceived graduate competence levels by staff) was rated significantly higher by employers compared to staff $(\mathrm{p}=<.05)$. 
Table 2: Staff ratings using a 7-point Likert scale of competencies important today, in 10 years' time, and perceived current graduate competency level, with comparison of 'important today' to graduate competency level (competency gap) ( $\mathrm{n}=46)$.

\begin{tabular}{|c|c|c|c|c|c|c|c|c|c|c|c|c|c|}
\hline & \multicolumn{3}{|c|}{ Important today } & \multicolumn{3}{|c|}{ Important in 10 years } & \multicolumn{3}{|c|}{$\begin{array}{l}\text { Current graduate competence } \\
\text { level }\end{array}$} & \multicolumn{2}{|c|}{$\begin{array}{l}\text { Difference today and } \\
10 \text { years' time }\end{array}$} & \multicolumn{2}{|c|}{$\begin{array}{l}\text { Difference today and } \\
\text { graduate competence }\end{array}$} \\
\hline & $\begin{array}{l}\text { Mean } \\
\text { rating }\end{array}$ & $\begin{array}{l} \pm 0.05 \\
\text { alpha } \\
\text { value }\end{array}$ & Ranking & Mean rating & $\begin{array}{l} \pm 0.05 \\
\text { alpha } \\
\text { value }\end{array}$ & Ranking & $\begin{array}{l}\text { Mean } \\
\text { rating }\end{array}$ & $\begin{array}{l} \pm 0.05 \\
\text { alpha } \\
\text { value }\end{array}$ & Ranking & $\begin{array}{c}\text { Size of } \\
\text { difference }\end{array}$ & Ranking & $\begin{array}{c}\text { Size of } \\
\text { difference }\end{array}$ & Ranking \\
\hline Problem solving & $6.65^{\#}$ & 0.1901 & 1 & $6.74^{*}$ & 0.1588 & 1 & 4.22 & 0.3686 & 13 & 0.00 & 24 & $2.50^{*}$ & 4 \\
\hline Critical thinking & $6.54^{\#}$ & 0.1950 & 2 & $6.74^{\sharp}$ & 0.1588 & 2 & 3.80 & 0.3615 & 17 & 0.20 & 13 & $2.70^{*}$ & 1 \\
\hline Written communication & 6.50 & 0.7226 & 3 & 6.57 & 0.7499 & 3 & 3.78 & 0.9744 & 18 & 0.10 & 21 & $2.70^{*}$ & 2 \\
\hline Self-management & $6.36^{\#}$ & 0.2255 & 5 & 6.56 & 0.2207 & 4 & 4.15 & 0.3593 & 14 & 0.20 & 17 & $2.20^{*}$ & 6 \\
\hline Oral communication & 6.41 & 0.2307 & 4 & 6.39 & 0.2691 & 10 & 4.44 & 0.2331 & 10 & 0.00 & 23 & $2.00^{*}$ & 10 \\
\hline Conceptual thinking & $6.26^{\#}$ & 0.2208 & 7 & $6.53^{\#}$ & 0.1962 & 8 & 3.77 & 0.3615 & 19 & 0.20 & 14 & $2.50^{*}$ & 3 \\
\hline Continuous learning & 6.25 & 0.2650 & 8 & 6.52 & 0.2438 & 9 & $4.43^{\&}$ & 0.3776 & 9 & 0.20 & 12 & $1.90^{*}$ & 13 \\
\hline Computer/ICT use & $6.27^{\#}$ & 0.2341 & 6 & 6.64 & 0.2488 & 5 & 5.55 & 0.3293 & 1 & 0.30 & 8 & $0.80^{*}$ & 25 \\
\hline Data analysis & $6.24^{\#}$ & 0.2912 & 9 & $6.60^{\#}$ & 0.2716 & 6 & $3.86^{*}$ & 0.3979 & 16 & 0.40 & 6 & $2.30^{*}$ & 5 \\
\hline Ethical responsibility & 6.18 & 0.2781 & 10 & 6.29 & 0.2875 & 11 & 4.25 & 0.3396 & 12 & 0.10 & 20 & $1.90^{*}$ & 12 \\
\hline Technical knowledge & $6.22^{\#}$ & 0.2863 & 11 & 6.09 & 0.3361 & 15 & 4.62 & 0.3307 & 3 & -0.10 & 25 & $1.60^{*}$ & 17 \\
\hline Help seeking & 6.11 & 0.2498 & 12 & 6.20 & 0.2685 & 13 & 4.53 & 0.4316 & 6 & 0.10 & 18 & $1.60^{*}$ & 18 \\
\hline Adaptability & 5.98 & 0.2438 & 13 & 6.23 & 0.3727 & 14 & 4.65 & 0.3297 & 2 & 0.20 & 10 & $1.30^{*}$ & 22 \\
\hline Creative thinking & 5.91 & 0.2851 & 14 & 6.33 & 0.2193 & 12 & 3.77 & 0.3727 & 20 & 0.40 & 7 & $2.10^{*}$ & 7 \\
\hline Project management & $5.91^{\#}$ & 0.3419 & 16 & 6.00 & 0.3596 & 17 & 3.82 & 0.3694 & 21 & 0.10 & 22 & $2.10^{*}$ & 8 \\
\hline Interpersonal relationships & 5.87 & 0.2731 & 15 & 5.78 & 0.3793 & 22 & $4.50^{\&}$ & 0.2970 & 8 & -0.10 & 26 & $1.40^{*}$ & 20 \\
\hline Societal responsibility & $5.76^{\#}$ & 0.3646 & 18 & 6.13 & 0.3502 & 16 & 4.05 & 0.3563 & 15 & 0.30 & 9 & $1.80^{*}$ & 14 \\
\hline Environmental sustainability & $5.76^{\#}$ & 0.3112 & 17 & $6.56^{\#}$ & 0.2727 & 7 & 4.27 & 0.3862 & 11 & $0.80^{*}$ & 2 & $1.50^{*}$ & 19 \\
\hline Teamwork & 5.84 & 0.3163 & 19 & 5.98 & 0.3379 & 18 & $4.59 \&$ & 0.3093 & 4 & 0.20 & 11 & $1.20^{*}$ & 23 \\
\hline Cultural awareness & 5.49 & 0.3267 & 20 & 6.02 & 0.3319 & 19 & 4.61 & 0.3959 & 5 & 0.50 & 4 & $0.90^{*}$ & 24 \\
\hline Financial literacy & $5.35^{\#}$ & 0.4116 & 21 & 5.50 & 0.4188 & 23 & 3.27 & 0.3699 & 25 & 0.20 & 15 & $2.00^{*}$ & 9 \\
\hline Staff-management & 5.33 & 0.4011 & 22 & 5.43 & 0.4367 & 25 & 3.50 & 0.3816 & 23 & 0.10 & 19 & $1.80^{*}$ & 16 \\
\hline Global awareness & $5.18^{\#}$ & 0.4117 & 24 & $5.91^{\#}$ & 0.3789 & 21 & 3.34 & 0.3000 & 24 & 0.70 & 3 & $1.90^{*}$ & 11 \\
\hline Digital interpersonal skills & 5.16 & 0.3689 & 23 & 6.04 & 0.3849 & 20 & 4.48 & 0.3706 & 7 & 0.80 & 1 & 0.70 & 26 \\
\hline Organisational awareness & 5.09 & 0.3587 & 26 & 5.33 & 0.3912 & 26 & 3.31 & 0.3682 & 26 & 0.20 & 16 & $1.80^{*}$ & 15 \\
\hline Leadership & 5.13 & 0.3575 & 25 & 5.50 & 0.3357 & 24 & 3.76 & 0.3359 & 22 & 0.40 & 5 & $1.30^{*}$ & 21 \\
\hline
\end{tabular}

$(\mathrm{p}=<.05)$. The \pm alpha provides the $95 \%$ confidence range; where ranges of competencies do not overlap the difference is significant $(\mathrm{p}=<.05)$. Ranking is descending order from highest rated competency to lowest or greatest gap between rating and performance to the least. 
When asked for their recommendations for enhancing students' work competencies in the openended anonymous survey question, staff thought a focus on key work competencies such as communication, teamwork, and analytical skills were essential:

Set expectations, rules, and boundaries about work performance and stick by them. Don't allow constant exceptions. Employers wouldn't (within the law), why does the university? Teach competent core skills that employers want, but also teach students how to think, critically evaluate and develop strategies to problem solve. This is generally woeful in our students, likely beaten out of them [sic] at high school. We need to bring it back. Also need to teach students it's ok not to know stuff and to ask questions about stuff they don't know - it doesn't mean they are dumb. (Academic Staff Participant 1; ASP1)

How to handle difficult situations involving working relationships with others. (ASP2)

Make space in curriculum for critical thinking, civics, politics...being less naive and/or accepting of status quo. (ASP3)

More group-based problem-oriented tasks. (ASP3)

Quantitative and technical skills... the future belongs to huge amount of information/data and rapid advances in technology - many of our students are rather weak and mostly phobic about things to technical or quantitative. (ASP4)

Giving students opportunities for work experience to enhance their application of ideas into practice including cross-disciplinary ways of working were also highlighted by staff to be important for supporting students' learning:

More opportunities for work placement for all students (as is being addressed by the [new curriculum]....).

More (higher level) assessment being focused on real problems, with multiple possible solutions, where

marks address more how a solution was developed, rather than the solution itself. (ASP5)

Exposure to more cross disciplinary issues - biologists need to better understand economics and political decision-making. (ASP6)

Finally, staff alluded to the importance of strengthening university-external organisations connections to offer more pathways for supporting students' developing important workplace competencies:

Offer an interface with businesses/employers in a workshop environment or through internships. (ASP7)

There needs to be continuous relationship development and engagement between the university and employer stakeholders. Stakeholders need to be confident that students [from the university] are employable. (ASP8)

\section{Discussion}

Today's diverse and complex work environments require science and engineering graduates with broader skillsets beyond technical knowledge and capabilities in order to compete and contribute productively to the local and global economy. With the increasing international focus of linking higher education with graduate employability outcomes (Bennett, Richardson, \& MacKinnon, 2016; Guilbert, Bernaud, Gouvernet, \& Rossier, 2016; Burke, Scurry, Blenkinsopp, \& Graley, 2016; Jackson, 2013; Mason, Williams, \& Cranmer, 2009; Rowe \& Zegwaard, 2017; Zegwaard \& Rowe, 2019) our study of science and engineering employers and university academic teaching staff views of the range of important work competencies graduates possess is timely in this global context. Science employers and engineering employers and academic teaching staff rated 26 competencies based on their 
perception of each competency's importance today, in 10 years' time, and, the competency level of recent graduates (within the last five years). Higher ratings depict higher importance and competency levels.

Overall, employers and academic staff view all competencies to be important but rated competencies such as problem solving and communication (written and oral) to be more important for today's workplaces confirming observations from others in the literature (e.g., Chiru, Ciuchete, Lefter, \& Paduretu, 2012; Passow, 2012; Smith et al., 2009). Staff rated the importance of problem solving to be higher than employers, however, academic staff believed current graduates underperformed in all competencies with the exception of digital interpersonal relationships. Both employers and staff ratings further highlighted the top 10 biggest gaps observed in competencies of importance today and graduates' competency include critical thinking, conceptual thinking, creative thinking, technical knowledge, and problem solving. This is disconcerting given these competencies are core components of the higher education curriculum and essential skills needed for careers in science and engineering. In focus groups, employers accepted that they need to train new graduates to improve their competence to the level they expected, and indicated that universities should not be expected to be able to 'fully train' every student. However, employers expressed the view that if university education included more authentic 'real problems' akin to those found in 'real-world workplaces', including work placements, work-related projects, workplace guest speakers, and involved closer engagement with organisations (workplaces), that students would likely develop these competencies further. Many of these examples were affirmed by university staff and fit within a broad definition of WIL that has been developed into the new university curriculum.

The findings are supported by recent studies recognising the value of active and authentic learning experiences such as flipped learning (Peter, Khoo, Cowie, Scott, \& Round, 2017; Scott, 2016) including various forms of WIL to be important in supporting students' developing professional competencies and attributes (Dressler \& Keeling, 2011; Jackson, 2013; Zegwaard et al., 2017; Zegwaard \& McCurdy, 2014). Others have gone further to investigate effective approaches to teaching/ fostering nontechnical competencies. For example, Ogot and Okudan (2006) highlight three distinctive ways such as embedding the competencies within current coursework, integrating and equally emphasising non-technical competencies alongside core technical competencies, and finally, supporting students to develop non-technical competencies independently of their core discipline. While a recent New Zealand based study of the kinds of teaching strategies employed by teachers in Institutes of Technology and Polytechnics to teach employability skills identified 84 teaching strategies that can be embedded in various degrees within coursework (Duignan et al., 2019).

Stakeholder views of competencies important in 10 years' time shifted to digital interpersonal skills and computer/ICT use. This was also confirmed in their views of the smallest gaps for competencies important today and graduates' competency levels, which included digital interpersonal skills, computer/ICT use and cultural awareness. These competencies align with global trends in digital and technological advancements in science and engineering (Sailer, Hense, Mandl, \& Klevers, 2017; World Economic Forum, 2018). Focus group feedback around this competency was that current graduates are well engaged with social media and other forms of digital communication and, therefore, have well-developed skills to convey understanding and emotion in digital forms. Employers provided further feedback that they saw digital interpersonal skills as an increasingly important competency for the future and an important aspect of their business.

A comparative study conducted in 2002 (Coll et al., 2002; Zegwaard \& Hodges, 2003) also sought employer and academic staff views of the important competencies today and in 10 years' time, using a similar sampling cohort as used for this study reported here. The 2002 study used different terms to describe the competencies (based on the work by Spencer \& Spencer, 1993), however, a comparison of the top 10 competencies shows near identical findings between the 2002 study and this study. For 
example, the 2002 study found that the top 10 competencies were an ability and willingness to learn, computer literacy, personal planning and organisational skills, teamwork and cooperation, analytical thinking, and flexibility, which are near identical to those in this study of continuous learning, computer/ICT use, self-management, teamwork, critical thinking, and adaptability. These findings suggest there has been little shift in importance of competencies over the 16 year since the 2002 study was completed. Of note, the 2002 study also included data of the important competencies in 10 years' time which indicated shifting importance (like this study also shows); however, this study was conducted 16 years after the 2002 study but yet has findings that are more similar to the 2002 'today' data rather than the 2002 ' 10 years' time's data. These comparisons suggest that employers and academic staff have perceptional bias to future shifting of importance of competencies that may not occur.

Academic staff rated all competencies as important and tended to rate the importance of competencies higher than employers. They, however, rated perceived graduate competency performance lower $(\mathrm{p}=<.05)$ than importance for every competency except digital interpersonal skills, and had a slight tendency to rate graduate competencies performance lower than employers (statistically significant for four competencies). This highlights a paradox where the staff responsible for developing graduate competencies believe graduates are not performing to the expected level of importance. In part, this could be explained by teaching staff tendency to set ambitious expectations of learning for students with the focus of furthering students' abilities; however, more likely academic staff are identifying that current curricular design does not allow the full extent of competency development required for graduates entering the workplace. This possibility is supported by employer and academic staff feedback that argued for greater interaction with relevant workplaces and integration of workplace learning (e.g., work placements, authentic tasks, guest lecturers) within the university curriculum.

The challenge for educators in designing a curriculum with a focus on enhancing employability outcomes and developing key competencies is highlighted in this research as being important for science and engineering graduates entering the workplace (Bennett, Richardson, \& MacKinnon, 2016; Zegwaard, \& Rowe, 2019). Accredited engineering degrees typically have the requirement of compulsory work experience (e.g., 400 hours in Australia and 800 hours in New Zealand). These experiences grant engineering students the opportunity to practice engineering work within the context of an engineering workplace, providing opportunity to develop competencies that are difficult to enable with on-campus teaching. However, it is important during the work experience that appropriate assessment practices are used that enable students to recognise and enhance the learning of the competencies during the work experience (Daelmans, Hoogenboom, Scherpbier, Stehouwer, \& Van Der Vleuten, 2005; Gibbs, \& Simpson, 2005; Hambur, Rowe, \& Luc, 2002; Trevelyan, 2019). Albeit, there is no single agreed upon definition of WIL, many of the definitions in the literature clearly argue that the work experience should be an intentional component within the curriculum, and the need for integration between the work component and other learning activities in the engineering curriculum (Coll, \& Zegwaard, 2012; Dressler, \& Keeling, 2011; Mason, Williams, \& Cranmer, 2009; Trede, 2012). The careful design of the curriculum needs to be informed with an understanding of what competencies are important and also what competencies graduates are most lacking in.

Both employers and academic staff argued for a closer university-external organisation engagement with the delivery of university education as well the type of content that is delivered. This finding has been consistently supported in the literature (e.g., Coll et al., 2002; Zegwaard \& Coll, 2011; Jackson, 2013; Ferns, Russell, \& Smith, 2015). Stakeholders recognise that the practice of science and engineering, in addition to technical competencies, requires a diverse range of skills and attributes which potentially is more important for emerging professional success in the workplace than technical proficiencies. 


\section{Limitations and Further Research}

The research reported have some inherent limitations affecting the generalisability of the findings. The research included academic staff and employers involved with a single university within the context of New Zealand. Furthermore, the participant sample size (46 academic staff and 210 employers) and the reliance of perceptional data limits the extend of the findings.

Recommendations for further research include:

- Larger scale, cross institutional research not limited to a single country.

- Research investigating the impact of different employer stakeholder variables such as workplace size and engineering type, appointment level and number of years as a practicing scientist or engineer. Similarly, analysis allowing for similar variables of academic staff would be informative, especially to see if the new, younger scientist or engineers moving into science academia or engineering academia hold similar or different views of importance of competencies compared to more established science or engineering academic staff members.

- Comparable investigations across different disciplines. The original Coll et al. (2004) study was replicated at different institutions across sport, education, and business, allowing for comparisons of differences and similarities between different sectors.

- Non-perceptional data gathering to determine graduate competency performance by way of, for example, competency performance observations or testing of recent graduates in the workplace, to complement the perceptional data of competency importance and graduate competency performance. This research approach may require in-depth investigation of a single competency or perhaps a grouping of related competency within a range of contexts.

\section{Conclusion}

This research was intended to contribute to further ideas for effective curriculum design and review regarding the conceptions of a 'work-ready plus' (Naylor, 2016) science and engineering graduate for the 21st century. The findings identified that employers and academic staff thought all competencies were important and that employers thought nearly all competencies will be more important in 10 years' time. The research also found that perceived graduate performance was less than the importance of every competency except computer/ICT use and digital interpersonal skills. Academic staff and employers generally had similar views of importance, however, academic staff favoured problem solving, self-management, conceptual thinking and data analysis more highly whilst employers favoured teamwork more highly and had a slight tendency to rate graduate competencies higher. Comparison to similar research 16 years ago indicated very little shift in importance of competencies over time despite that earlier research indicating shifts in importance would occur. It is intended that this research will inform science and engineering curricular design, with emphasis on competencies developed through authentic and meaningful tasks similar to, or situated within, the relevant workplace.

\section{Acknowledgement}

The project team gratefully acknowledge funding support from the University of Waikato through the 2017 Strategic Investment Fund. We also acknowledge Professor Bronwen Cowie and Dr Mira Peter for their advice and guidance in contributing to this project. Components of the preliminary findings from this research have been presented at conferences (see Khoo, Zegwaard, \& Adam, 2018; Zegwaard, Khoo, \& Adam, 2018; Zegwaard, Khoo, Adam, \& Peter, 2018).

\section{Declaration of interest:}


No potential conflict of interest was reported by the authors.

\section{References}

AC Nielsen Research Services (2000). Employer satisfaction with graduate skills: Research report. Canberra: Department of Education, Training and Youth Affairs.

Archer, W., \& Davison, J. (2008). Graduate employability: What do employers think and want? Retrieved from London: www.cihe.co.uk/wp-content/themes/cihe/document.php?file=0802Grademployability.pdf

Barrie, S. (2006). Understanding what we mean by the generic attributes of graduates. Higher Education, 51, 215241.

Bennett, D., Richardson, S., \& MacKinnon, P. (2016). Enacting strategies for graduate employability: How universities can best support students to develop generic skills. Sydney: Australian Government Office for Learning and Teaching. Retrieved from https://melbournecshe.unimelb.edu.au/ data/assets/pdf file/0005/1874777/SP13-3258-Curtin Bennett- GraduateEmployability Part-B-Appendices1.pdf

Birkett, W. P. (1993). Competency based standards for professional accountants in Australia and New Zealand, Retrieved from Melbourne, Australia:

Bowen, T. \& Pennaforte, A. (2017). The Impact of Digital Communication Technologies and New RemoteWorking Cultures on the Socialization and Work-Readiness of Individuals in WIL Programs. In T. Bowen \& M. T. B. Drysdale (Eds.), Work-integrated learning in the 21st century: Global perspectives on the future (pp. 99-112). Bingley, UK: Emerald Publishing Limited.

Braun, V., \& Clarke, V. (2006). Using thematic analysis in psychology. Qualitative Research in Psychology, 3(2), 77101.

Burke, C., Scurry, T., Blenkinsopp, J., \& Graley, K. (2016). Critical perspectives on graduate employability. In M. Tomlinson \& L. Holmes (Eds.), Graduate employability in context (pp. 87- 107). London: Palgrave Macmillan. doi: 10.1057/978-1-137-57168-7_4

Campbell, M., \& Zegwaard, K. E. (2015). Developing critical moral agency through workplace engagement. In M. Kennedy, S. Billett, S. Gherardi, \& L. Grealish (Eds.), Practice-based learning in higher education: Jostling cultures (pp. 47-64). Dordrecht, The Netherlands: Springer.

Chhinzer, N., \& Russo, A. M. (2018). An exploration of employer perceptions of graduate student employability. Education + Training, 60(1), 104-120.

Chiru, C., Ciuchete, S. G., Lefter, G. G., \& Paduretu, E. (2012). A Cross Country Study on University Graduates Key Competencies. An Employer's Perspective. Procedia - Social and Behavioral Sciences, 46, 4258-4262. doi:https://doi.org/10.1016/j.sbspro.2012.06.237

Coll, R. K., \& Zegwaard, K. E. (2012). Enculturation into engineering professional practice: Using legitimate peripheral participation to develop communication skills in engineering students. In A. Patil, H. Eijkman, \& E. Bhattacharyya (Eds.), New media communication skills for engineers and IT professionals: Trans-national and trans-cultural demands (pp. 22-33). Hersey, PA: Information Science Reference.

Coll, R. K., Zegwaard, K. E., \& Hodges, D. (2002). Science and technology stakeholders' ranking of graduate competencies part 1: Employer perspective. Asia-Pacific Journal of Cooperative Education, 3(2), 19-28.

Daelmans, H. E. M., Hoogenboom, R. J. I., Scherpbier, A. J. J. A., Stehouwer, C. D. A., \& Van Der Vleuten, C. P. M. (2005). Effects of an in-training assessment programme on supervision of and feedback on competencies in an undergraduate internal medicine clerkship. Medical Teacher, 27(2), 158-163.

De Graaff, E., \& Ravesteijn, W. (2001). Training complete engineers: Global enterprise and engineering education. European Journal of Engineering Education, 26(4), 419-427.

Dowling, D., \& Hadgraft, R. (2013). A graduate capability framework for environmental engineering degree programs: A guide for Australian universities. Retrieved from Sydney, Australia: https://pdfs.semanticscholar.org/105b/2de4e02afec5c66cdb4914f59b03306f6171.pdf

Dressler, S., \& Keeling, A. E. (2011). Benefits of cooperative and work-integrated education for students. In R. K. Coll \& K. E. Zegwaard (Eds.), International handbook for cooperative and work-integrated education: International perspectives of theory, research and practice (2nd ed., pp. 261-275). Lowell, MA: World Association for Cooperative Education.

Duignan, G., Casley, S., Fraser, C., Haggerty, C., Hannam, S., Hitchcock, B., . . Webster, A. (2019). Teaching strategies that build employability skills of vocational education graduates. Retrieved from Wellington, New Zealand: https://ako.ac.nz/knowledge-centre/teaching-strategies-that-build-employability/teachingstrategies-that-build-employability-skills-of-vocational-education-graduates/ 
Farahani, M. F., \& Farahani, F. F. (2014). The Study on Professional Ethics Components among Faculty Members in the Engineering. Procedia - Social and Behavioral Sciences, 116, 2085-2089. doi:http://dx.doi.org/10.1016/j.sbspro.2014.01.524

Fleming, J., Martin, A. J., Hughes, H., \& Zinn, C. (2009). Maximizing work-integrated learning experiences through identifying graduate competencies for employability: A case study of sport studies in higher education. Asia-pacific Journal of Cooperative Education (Special Issue), 10(3), 189-201.

Ferns, S., Russell, L., \& Smith, C. (2015). Designing work-integrated learning to optimise student employment readiness. In T. Thomas, E. Levin, K. Dawson, K. Fraser, \& R. Hadcraft (Eds.), Research and development in higher education: Learning for life and work in a complex world. Higher Education Research and Development Society of Australasia (HERDSA).

Friesen, M., \& Ingram, S. (2013). Advancing intercultural competency: Canadian engineering employers' experiences with immigrant engineers. European Journal of Engineering Education, 38(2), 219-227.

Greene, J. C., \& Caracelli, V. J. (1997). Defining and describing the paradigm issue in mixed-method evaluation. New directions for evaluation, 1997(74), 5-17. doi:https://doi.org/10.1002/ev.1068

Gibbs, G., \& Simpson, C. (2005). Conditions under which assessment supports students' learning. Learning and teaching in higher education, (1), 3-31.

Guilbert, L., Bernaud, J. L., Gouvernet, B., \& Rossier, J. (2016). Employability: review and research prospects. International Journal for Educational and Vocational Guidance, 16(1), 69-89.

Hambur, S., Rowe, K., \& Luc, L. T. (2002). Graduate skills assessment. Stage One Validity Study. Canberra: Australian Council for Educational Research. Retrieved from https://www.acer.org/files/GSA ValidityStudy.pdf

Harvey, L. (2000). New realities: The relationship between higher education and employment. Tertiary Education and Management, 6(1), 3-17. doi:10.1080/13583883.2000.9967007

Hubbard, E. M. (2012). Developing systems engineering competencies in undergraduate students for industrial placements. INCOSE International Symposium, 22(1), 1379-1386. doi:10.1002/j.2334-5837.2012.tb01409.x

Ishkov, A., \& Magera, T. (2015). Emotional competency in an engineering university: yes or no?, Procedia Engineering, 117, 148-153.

Jackson, D. (2012). Non-technical skill gaps in Australian business graduates. Education + Training, 54(2/3), 95-113. doi:doi.org/10.1108/00400911211210224

Jackson, D. (2013). The contribution of work-integrated learning to undergraduate employability skill outcomes Asia-Pacific Journal of Cooperative Education, 14(2), 99-115.

Jainudin, N. A., Francis, L., Tawie, R., \& Matarul, J. (2015). Competency of Civil Engineering Students Undergone Industrial Training: Supervisors' Perspectives. Procedia - Social and Behavioral Sciences, 167, 245-249. doi:https://doi.org/10.1016/j.sbspro.2014.12.669

Jameson, A., Carthy, A., McGuinness, C., \& McSweeney, F. (2016). Emotional Intelligence and Graduates Employers' Perspectives. Procedia - Social and Behavioral Sciences, 228, 515-522. doi:https://doi.org/10.1016/j.sbspro.2016.07.079

Kennedy, M., Billett, S., Gherardi, S., \& Grealish, L. (2015). Practice-Based Learning in Higher Education: Jostling Cultures. In M. Kennedy, S. Billett, S. Gherardi, \& L. Grealish (Eds.), Practice-based Learning in Higher Education: Jostling Cultures (pp. 1-13). Dordrecht: Springer Netherlands.

Khoo, E., Zegwaard, K. E.,\& Adam, A. (2018). Employer and lecturer perceptions of science and engineering graduate competencies: Implications for curricular and pedagogical practice. In: 29th Australasian Association for Engineering Education Conference 2018 (AAEE 2018). Hamilton, New Zealand: Engineers Australia (pp. 377-384). Availability: https://search.informit.com.au/documentSummary;dn=169118551956010;res=IELENG

Khoo, E., Zegwaard, K. E., Adam, A., Peter, M., \& Cowie, B. (2017a, November). A collaborative framework for enhancing graduate competencies through university-industry partnerships. Paper presented at the New Zealand Association of Research in Education (NZARE2017), Hamilton, New Zealand.

Khoo, E., Zegwaard, K., Peter, M., Adam, A., \& Cowie, B. (2017b). Exploring science and engineering stakeholder views of the essential competencies for the 21st century workplace. Retrieved from https://www.waikato.ac.nz/wmier/projects/exploring-science-and-engineering-for-essential-21stcentury-competencies

Kubečková, D. (2014). Lifelong Learning as a Part of Training in the Field of Civil Engineering. Procedia - Social and Behavioral Sciences, 141, 623-627. doi:https://doi.org/10.1016/j.sbspro.2014.05.109

Lucena, J., Downey, G., Jesiek, B., \& Elber, S. (2008). Competencies Beyond Countries: The Re-Organization of Engineering Education in the United States, Europe, and Latin America. Journal of engineering education, 97(4), 433-447. 
Lukasz Maciej, M., \& Shi-Jie, C. (2010). Evaluation of industrial engineering students' competencies for process improvement in hospitals. Journal of Industrial Engineering and Management, 3(3), 603-628. doi:10.3926/jiem..v3n3.p603-628

Lizunkov, V., Marchuk, V., \& Podzorova, E. (2015). Identification of criteria, features and levels of economic and managerial competencies development for Bachelors in Mechanical Engineering. Procedia - Social and Behavioral Sciences, 206(388-393). doi:http://dx.doi.org/10.1016/j.sbspro.2015.10.071

Male, S. A., Bush, M. B., \& Chapman, E. S. (2011). An Australian study of generic competencies required by engineers. European Journal of Engineering Education, 36(2), 151-163.

Mason, G., Williams, G., \& Cranmer, S. (2009). Employability skills initiatives in higher education: what effects do they have on graduate labour market outcomes? Education Economics, 17(1), 1-30.

Miloradova, N., \& Ishkov, A. (2015). Environmental Ethics as a Social, Professional and Personal Value of the Students of Civil Engineering University. Procedia Engineering, 117, 246-251. doi:http://dx.doi.org/10.1016/j.proeng.2015.08.158

Ministry of Education. (2016). Employability skills framework. Retrieved from Wellington, New Zealand: https://youthguarantee.education.govt.nz/tools/employability-skills/employability-skills-framework/

Ministry of Education. (2019). Shaping a stronger education system with New Zealanders. Retrieved from Wellington, New Zealand: https://conversation.education.govt.nz/assets/Uploads/Discussion-Document-Shaping-aStronger-Education-System-with-NZers-Final19.pdf

Ministry of Education, \& Ministry of Business, I. a. E. (2014). Tertiary education strategy 2014-2019. Retrieved from Wellington, New Zealand: https://www.education.govt.nz/further-education/policies-andstrategies/tertiary-education-strategy/

Mulder, M., Weigel, T., \& Collins, K. (2007). The concept for competence in the development of vocational education and training in selected EU member states: a critical analysis. Journal of Vocational Education and Training, 59(1), 67-88.

Nair, C. S., Patil, A., \& Mertova, P. (2009). Re-engineering graduate skills-a case study. European Journal of engineering education, 34(2), 131-139.

Naylor, S. (2016). Making tertiary studies in engineering more relevant. Retrieved from Dunedin, New Zealand: http://www.tec.govt.nz/assets/Reports/33c28aac3c/Making-Tertiary-Studies-In-Engineering-MoreRelevant.pdf?r=1

Ogot, M., \& Okudan, G. E. (2006). Integrating systematic creativity into first-year engineering design curriculum. International journal of Engineering Education, 22(1), 109-115.

Passow, H. J., \& Passow, C. H. (2017). What competencies should undergraduate engineering programs emphasize? A systematic review. Journal of Engineering Education, 106(3), 475-526.

Passow, H. J. (2012). Which ABET competencies do engineering graduates find most important in their work? Journal of Engineering Education, 101(1), 95-118.

Peter, M., Khoo, E., Cowie, B., Scott, J., \& Round, H. (2017). Reengineering an engineering course: How flipped classrooms afford transformative teaching, learning, and workplace competency. Retrieved from http://www.tlri.org.nz/sites/default/files/projects/TLRI\%20Summary Peter\%26Khoo.pdf

Pons, D. J. (2016). Relative importance of professional practice and engineering management competencies. European Journal of Engineering Education, 41(5), 530-547.

Pons, D. J. (2015). Changing importances of professional practice competencies over an engineering career. Journal of Engineering and Technology Management, 38, 89-101. doi: https://doi.org/10.1016/j.jengtecman.2015.10.001

Ramlutchman, N. (2013). Intercultural communication and work integrated learning: A South African perspective. Journal of economics and behavioral studies, 5(3), 148-156.

Rowe, A. D., \& Zegwaard, K. E. (2017). Developing graduate employability skills and attributes: Curriculum enhancement through work-integrated learning [Special issue]. Asia-Pacific Journal of Cooperative Education, 18(2), 87-99.

Sailer, M., Hense, J., Mandl, H., \& Klevers, M. (2017). Fostering Development of Work Competencies and Motivation via Gamification. In M. Mulder (Ed), Competence-based Vocational and Professional Education. Technical and Vocational Education and Training: Issues, Concerns and Prospects (pp. 795-818). Cham: Springer. https://doi.org/10.1007/978-3-319-41713-4_37

Scott, G. (2016). Assuring the Quality of Achievement Standards and Their Valid Assessment in Australian Higher Education: Final Report May, 2016. Canberra: Australian Government, Department of Education and Training. Retrieved from http://flipcurric.edu.au/sites/flipcurric/media/109.pdf

Scott, G., Chang, E., \& Grebennikov, L. (2010). Using successful graduates to improve the quality of undergraduate nursing programs. Journal of Teaching and Learning for Graduate Employability, 1(1), $26-44$. 
Scott, G., \& Yates, W. (2002). Using successful graduates to improve the quality of undergraduate engineering programs. European Journal of Engineering Education, 27(4), 363-378.

Shnyrenkov, E., \&Pryadko, I. (2015). The Bologna Process: exacerbation of social competencesamong civil engineering students. Procedia engineering, 117, 330-335.

Singh, P., Thambusamy, R. X., \& Ramly, M. A. (2014). Fit or Unfit? Perspectives of Employers and University Instructors of Graduates' Generic Skills. Procedia - Social and Behavioral Sciences, 123, 315-324. doi: https://doi.org/10.1016/j.sbspro.2014.01.1429

Smith, M., Brooks, S., Lichtenberg, A., McIlveen, P., Torjul, P., \& Tyler, J. (2009). Career development learning: Maximising the contribution of work-integrated learning to the student experience. Final project report June 2009. University of Wollongong. Retrieved from https://eprints.usq.edu.au/5401/3/Smith_et_al_ALTC_Report_2009_PV.pdf

Spencer, L. M., \& Spencer, S. M. (1993). Competence at work. New York: Wiley.

Trede, F. (2012). Role of work-integrated learning in developing professionalism and professional identity. International Journal of Work-Integrated Learning, 13(3), 159-167.

Trevelyan, J. (2019). Transitioning to engineering practice. European Journal of Engineering Education, 44(6), 821837.

Weisz, M. (2000). Developing a measure of students attributes. Journal of Cooperative Education, 35(2-3), 33-40.

Williams, J., \& Walkington, J. (2015). The role of epistemology in practice-based learning: The case of artifacts. In M. Kennedy, S. Billett, S. Gherardi, \& L. Grealish (Eds.), Practice-Based Learning in Higher Education: Jostling Cultures (pp. 99-110). Dordrecht: Springer Netherlands.

World Economic Forum. (2018). The future of jobs report 2018, World Economic Forum, Geneva, Switzerland. Retrieved from https://www.voced.edu.au/content/ngv:80780

Yadav A., Good J., Voogt J., Fisser P. (2017). Computational Thinking as an Emerging Competence Domain. In M. Mulder (Ed.), Competence-based Vocational and Professional Education. Technical and Vocational Education and Training: Issues, Concerns and Prospects (pp. 1051-1067). Cham: Springer. https://doi.org/10.1007/978-3319-41713-4 49

Zegwaard, K. E., Campbell, M., \& Pretti, T. J. (2017). Professional identities and ethics: The role of workintegrated learning in developing agentic professionals. In T. Bowen \& M. T. B. Drysdale (Eds.), Workintegrated learning in the 21st century: Global perspectives on the future (pp. 145-160). Bingley, UK: Emerald Publishing Limited.

Zegwaard, K. E., \& Coll, R. K. (2011). Using cooperative and work-integrated education to provide career clarification. Science Education International, 22(4), 282-291.

Zegwaard, K. E., \& Hodges, D. (2003). Science and technology stakeholders' ranking of graduate competencies part 4: Faculty perspective. Asia-Pacific Journal of Cooperative Education, 4(2), 23-35.

Zegwaard, K. E., Khoo, E., \& Adam, A. (2018). Graduate competencies and competence: Science and engineering employers' perspectives. In K. E. Zegwaard \& M. Ford (Eds), Refereed Proceedings of the $3^{\text {nd }}$ International Research Symposium on Cooperative and Work-Integrated Education, Stuttgart, Germany (pp. 273-279). Hamilton, New Zealand: University of Waikato.

Zegwaard, K. E., Khoo, E., Adam, A., \& Peter, M. (2018). The shifting perceptions by science and engineering employers of desirable graduate competencies: Comparing now to 16 years ago. In K. E. Zegwaard \& K. Hoskyn (Eds.), New Zealand Association for Cooperative Education 2018 Conference Proceedings (pp. 53-57). New Zealand Association for Cooperative Education.

Zegwaard, K. E., \& McCurdy, S. (2014). The influence of work-integrated learning on motivation to undertake graduate studies Asia-Pacific Journal of Cooperative Education, 15(1), 13-28.

Zegwaard, K. E., \& Rowe, A. D. (2019). Research-informed curriculum and advancing innovative practices in work-integrated learning. International Journal of Work-Integrated Learning, 20(4), 323-334. 
Appendix 1. Dimensions of competencies and relevant literature sources

\begin{tabular}{|c|c|}
\hline Dimensions of Competencies & Examples of relevant literature \\
\hline $\begin{array}{l}\text { Communication and Teamwork } \\
\text { skills - oral communication, written } \\
\text { communication, interpersonal } \\
\text { relationship, digital interpersonal } \\
\text { skills and teamwork }\end{array}$ & $\begin{array}{l}\text { AC Nielsen (2000) } \\
\text { Bowen \& Pennaforte (2017) } \\
\text { Chiru, Ciuchete, Lefter, \& Paduretu (2012) } \\
\text { Coll, Zegwaard, \& Hodges (2002) } \\
\text { Coll \& Zegwaard (2012) } \\
\text { De Graaff \& Ravesteijn (2001) } \\
\text { Fleming, Martin, Hughes, \& Zinn (2009) } \\
\text { Hambur, Rowe, \& Luc (2002) } \\
\text { Jainudin, Francis, Tawie, \& Matarul (2015) } \\
\text { Male, Bush, \& Chapman (2011). } \\
\text { Nair, Patil, \& Mertova (2009). } \\
\text { Passow (2012) } \\
\text { Ramlutchman (2013) } \\
\text { Sailer, Hense, Mandl, Klevers (2017) } \\
\text { Singh, Thambusamy, \& Ramly (2014) } \\
\text { Smith et al. (2009) } \\
\text { Pons (2015) } \\
\text { Pons (2016) } \\
\text { Shnyrenkov \& Pryadko (2015) }\end{array}$ \\
\hline $\begin{array}{l}\text { Leadership and Management skills - } \\
\text { leadership, staff management, project } \\
\text { management, financial literacy, } \\
\text { organisational awareness }\end{array}$ & $\begin{array}{l}\text { AC Nielsen (2000) } \\
\text { Coll et al. (2002) } \\
\text { De Graaff \& Ravesteijn (2001) } \\
\text { Fleming, Martin, Hughes, \& Zinn (2009) } \\
\text { Lizunkov, Marchuk, \& Podzorova (2015) } \\
\text { Nair, Patil, \& Mertova (2009) } \\
\text { Pons (2015) } \\
\text { Pons (2016) } \\
\text { Smith et al. (2009) } \\
\text { Trede (2012) }\end{array}$ \\
\hline $\begin{array}{l}\text { Analytical skills - problem solving, } \\
\text { data analysis, critical thinking, } \\
\text { conceptual thinking, creative } \\
\text { thinking, conceptual knowledge }\end{array}$ & $\begin{array}{l}\text { AC Nielsen (2000) } \\
\text { Coll et al. (2002) } \\
\text { Chiru, Ciuchete, Lefter, \& Paduretu (2012) } \\
\text { Hambur, Rowe, \& Luc (2002) } \\
\text { Lizunkov et al. (2015) } \\
\text { Passow (2012) } \\
\text { Smith et al. (2009) } \\
\text { Yadav, Good, Voogt, \& Fisser (2017) } \\
\text { Lukasz Maciej \& Shi-Jie (2010) }\end{array}$ \\
\hline
\end{tabular}




\begin{tabular}{|c|c|}
\hline $\begin{array}{l}\text { Lifelong Learning and Self- } \\
\text { Management skills - computer/ICT } \\
\text { skills, self-management, adaptability, } \\
\text { help seeking, continuous learning }\end{array}$ & $\begin{array}{l}\text { AC Nielsen (2000) } \\
\text { Coll et al. (2002) } \\
\text { Harvey (2000) } \\
\text { Ishkov \& Magera (2015) } \\
\text { Fleming, Martin, Hughes, \& Zinn, (2009) } \\
\text { Jameson, Carthy, McGuinness, \& McSweeney (2016) } \\
\text { Kubečková (2014) } \\
\text { Male, Bush, \& Chapman (2011) } \\
\text { Sailer, Hense, Mandl, Klevers (2017) } \\
\text { Smith et al. (2009) } \\
\text { Williams \& Walkington (2015) }\end{array}$ \\
\hline $\begin{array}{l}\text { Global Awareness skills - } \\
\text { environmental sustainability, societal } \\
\text { responsibility, ethical responsibility, } \\
\text { cultural awareness, and global } \\
\text { awareness }\end{array}$ & $\begin{array}{l}\text { Chiru, Ciuchete, Lefter, \& Paduretu (2012) } \\
\text { Campbell \& Zegwaard (2015) } \\
\text { Farahani \& Farahani (2014) } \\
\text { Friesen \& Ingram (2013) } \\
\text { Kennedy, Billett, Gherardi, \& Grealish (2015) } \\
\text { Lucena, Downey, Jesiek, \& Elber (2008) } \\
\text { Lizunkov et al. (2015) } \\
\text { Miloradova \& Ishkov (2015) } \\
\text { Pons (2015) }\end{array}$ \\
\hline
\end{tabular}


Appendix 2. Definition of survey items

\section{Communication and teamwork skills}

Oral communication (effective verbal communication with various audiences across different situations and contexts)

Written communication (writing clear emails, technical reports, letters, etc. for various audiences) Interpersonal relationships (can get along with, understand, and empathise with others)

Digital interpersonal skills (can present a reputable online digital identity, communicate with and understand others in a digital space)

Teamwork (can work effectively with groups of diverse people)

\section{Leadership and management skills}

Leadership (can draw together, enthuse and lead people effectively towards achieving a vision or a goal)

Staff management (can effectively organise a team)

Project management (can effectively plan, oversee and complete individual or group projects)

Financial literacy (can understand financial information, such as budgets and make financially sound decisions)

Organisational awareness (recognises organisational structure and relevant culture)

\section{Analytical Skills}

Problem solving (can identify aspects of a problem, analyse and develop solutions to solve it)

Data analysis (can analyse, interpret and explain quantitative and qualitative data)

Critical thinking (can think clearly and rationally about appropriate actions in a range of situations)

Conceptual thinking (can apply concepts and theories to a task)

Creative thinking (can offer new, innovative ideas and solutions to an issue)

Technical knowledge (can undertake practical tasks specific to the discipline of practice)

\section{Lifelong learning and self-management skills}

Self-management (can self-organise, prioritise and structure work)

Adaptability (willing to learn to fit and adjust into new or changing organisational culture, ethics and values)

Help seeking (can effectively learn from peers and confident to ask questions when needing help from others)

Continuous learning (can and willing to continuously learn to advance professional and selfdevelopment)

Computer/ICT use (can use online platforms, software and apps, etc)

\section{Global awareness}

Environmental sustainability (awareness of non-wasteful and/or sustainable use of resources)

Societal responsibility (understanding one's responsibility in society as a professional practitioner and community member)

Ethical responsibility (understands professional values and principles, considers consequences for others)

Cultural awareness (can embrace similarities and differences among cultures and be openminded to differences)

Global awareness (understands and considers international politics and economic issues relevant to one's practice) 